\title{
鋳鉄のエレクトロスラグ溶接（第2報）*
}

（試作フラックスに関する $2 ， 3 の$ 検討）

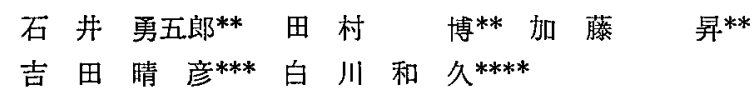

Electroslag Welding of Cast Iron (Report 2)*

(Some investigations on experimentally produced fluxes)

by Yugoro Ishii**, Hiroshi Tamura**, Noboru Kato**, Haruhiko Yoshida*** and Kazuhisa Shirakawa****

\begin{abstract}
As described in the last report, ${ }^{1}$ it was known that electroslag welding of cast iron can be exected by use of a cored wire $\left(\mathrm{Fe}_{3} \mathrm{C}+\mathrm{Fe}-\mathrm{Si}\right)$ and a hollow graphite nozzle. This welding, however, has been somewhat unstable; as one reason for this instability may be mentioned the adoption of commercial flux for mild steel. Since the melting point of cast iron is only slightly higher than that of the commercial flux, slag inclusion is liable to happen and the welding results tend to be poor.

Thereupon, with mainly the aim to develop a welding flux that can produce a lower temperature fusible slag, several types of flux were prepared; the electroslag welding of cast iron plates using them were investigated. Meanwhile, the performances of these fluxes were compared by measuring the physical properties, such as viscosity and electric resistance of welding slag. Furthermore, the dynamic behavior of the molten slag during welding was observed by X-ray inspection. Finally there were discribed the results of repair welding practically applied on defects of large machine tool tables using the flux E6 selected from the results in this study.
\end{abstract}

1. 緒

電

前報】では，白釷鉄粉末充填ワイヤと黒鉛ノズル電極 を用いた新しい鋳鉄用エレクトロスラグ溶接法を開発 し, 組成, 色調, 振動减衰率, 硬さ, 強度とも母材とほ とんど差のない溶接を行うことができたてとを報告し た.

しかし，フラックスは市販の鋼用のものをそのまま用 いたため, 溶接境界部にスラグ巻込などの欠宿が生じた りして溶接の安定性にそしかった。

鋳鉄のエレクトロスラグ溶接用スラグは，溶接時には $1200^{\circ} \mathrm{C} \sim 1700^{\circ} \mathrm{C}$ くらいの温度に加熱されているが，乙 の鋳鉄用スラグに必要な主な条件は， $1700^{\circ} \mathrm{C}$ 付近での 高温であ粘性や電気抵抗が極端に小さくならないとと や,アークの不安定性などのほかに, 鋳鉄の凝固温度で ある $1200^{\circ} \mathrm{C}$ 罗付近での粘性および電気伝導度が適度であ

\footnotetext{
*. 原稿受付 昭和48年 5 月23日（44年度秋全国大会に發表）

** 正 員 東京工業大学 Member, Tokyo Institute of Technology

****学生員 東宗工䅈大学 Student Member, Tokyo Institute of Technology

**** 東京工業大学 "Tokyo Institute of Technology
}

るととがあげられる。

しかしながら，既存の市販エレクトロスラグ用フラッ クスは鋼用としてつくられているので，その融点は 1250 $\sim 1450^{\circ} \mathrm{C}$ に限定されている. そのため, 鋼の凝固温度 付近では，スラグは完全に溶融していて適度の粘性と電 導度を持つが，鋳鉄の凝固温度である $1200^{\circ} \mathrm{C}$ 付近での 粘性はかなり高く，スラグ巻込などの欠楩をつくる原因 となっている。

黒鉊ノズル式エレクトロスラグ溶接に必要なスラグの 特性としては，以上のほかに，スラグ組成のうちの溶融 酸化物が，炭素などによってあまり遠元されないとと や，蒸気圧が高いととによる成分の気化などによってス ラグの物性が変化しないととが望まれる。

しかしながら，以上の諸性質を同時汇満足するスラグ をつくることは一般に困難なので，本報告では低融点ス ラグの開発に主眼をおき研究を進めた。

\section{2. スラグの組成}

多くのスラグは, 電導度が大きく, 融点の低い $\mathrm{CaF}_{2}$ (融点約 $1350^{\circ} \mathrm{C}$ ) をべースとしてつくられている. 
この $\mathrm{CaF}_{2}$ は，各種の介在物に対するぬれ性あ非常に よいため，脱介在物性に俊れているなど多くの利点をる つ.しかしながら，ての $\mathrm{CaF}_{2}$ を単体として釷鉄の溶接 に使用する場合は，それでもなお融点が高過ぎたり，電 導度が大き過ぎたりして適切ではない。

一般市販の軟鋼溶接用フラックスは $\mathrm{CaO}_{2}$ のほかに $\mathrm{CaO}, \mathrm{MgO}, \mathrm{Al}_{2} \mathrm{O}_{3}, \mathrm{SiO}_{2}, \mathrm{MnO}$ などを配合して適度の粘 性之電導度が得られている。一般に粘性を下げる成分と しては $\mathrm{CaF}_{2}, \mathrm{CaO}, \mathrm{TiO}_{2}$ などがあり，電導度を下げる 成分として $\mathrm{Al}_{2} \mathrm{O}_{3}, \mathrm{SiO}_{2}, \mathrm{TiO}_{2}$ などがあげられる，しか しながら 4 元系以上のスラグの, 各温度での粘性および 電導度を知るための状態図がほとんどないこともあっ て，多くの溶接フラックスは試行錯誤の結果つくられて いる.

水野，松村2つらは，この粘性および電導度と組成との 関係を示す共通のパラメーターとして $\left(\mathrm{NCaO}_{2}+2.2\right.$ $\left.\mathrm{NCaF}_{2}\right) /\left(\mathrm{NSiO}_{2}+\mathrm{NAl}_{2} \mathrm{O}_{3}\right)$ をとり，乙れによってり連 の Paton 研究所によって開発されたいくつかのスラグ を整理したところ，電導度および粘性が一つの曲線によ って表示できたとしている。すなわち，このパラメータ の mol\%kよる值が大きい場合は，電導度が大きくな るとともに粘性が小さくなる。このように組成によって スラグの物性をある程度までは推定することは可能であ るが，粘性と電導度とが同じパラメーターで表わせる関 係上，電導度を変えないで粘性だけを低下させることは むずかしい。

本研究では，鋳鉄の溶接に適したスラグ組成をきめる にあたりセラミックスの状態図るを参考にしたものああ るが，既存スラグの粘性を低下させるととを主目的に組 成を检討し，フラッグスを試作した。

実験に用いたスラグの組成を Table1 亿示す。

A〜E6 のフラックス組成はそれぞ扎以下の理由によ り選定した。

1）セミラックスの状態図の中から選んだ低い粘性をも つおの（フラックスAおよびB）

2）既存フラックスのうちであ出較的粘性が低い亡思わ れるすの(フラックス C……連で開発された鋼用フ ラックス $\mathrm{AN}-25^{4)} \ldots . . . \mathrm{CaF}_{2}$ が37\%入っているほ加に，
低粘性，低電導の特異效果 5 をる $\mathrm{TiO}_{2}$ が35\%入っ ている)

3）前報1での「鋳鉄のエレクトロスラグ溶接」に用い たもの（市販フラックス E1）

4） $\mathrm{E} 1$ 亿 $\mathrm{CaF}_{2}$ を添加して融点を低下させたすの（つ ラックス $\mathrm{E} 3, \mathrm{E} 6$ )

\section{3. スラグの物性}

上記の各種フラックスがよ゙のような物性を示すかを知 るととは，とれからの溶接現象を観察するうえで，きわ めて重要であると思われる。

なかでる，粘性と電導度は，ガスの脱出，スラグ巻 迂，発熱量，溶接安定性などの点で溶接に大きな影響を 与える因子であるので, まずとれらの測定を行なった.

\section{1 粘度の測定法およひ結果}

粘度の測定は，いろいろな方法が行われているが，本 実験では回転円筒法を用いて测定した。この方法は広い 温度笧团の粘性を連続的に測定することが可能であり， 测定可能な粘性範团す $0.1 \sim 10^{4}$ ポアズで適当である.

回転円筒の材料としては, 一般には白金, モリブデ ン，黒鉛，アルミナ，マグネシヤなどの酎火物が考えら れるが，成形の難易，経済性などを考慮して，黒鉊を用 いた，粘性測定装犆を，Fig. 1 に示す。ルツボにスラグ

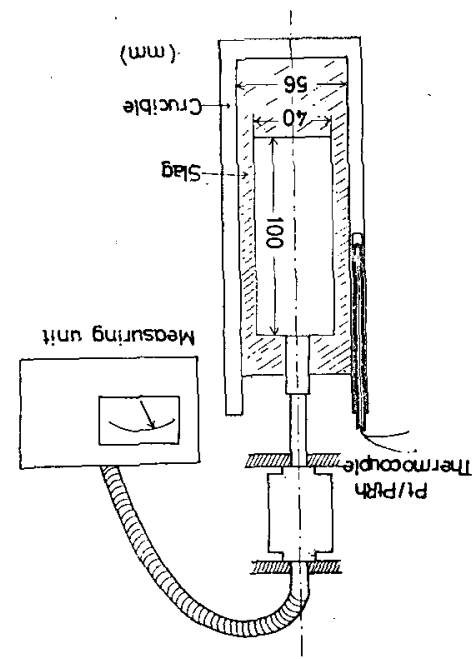

Fig. 1 Measuring apparatus for viscosity of molten slag.

Table 1 Chemical analysis of welding fluxes tested.

\begin{tabular}{|c|c|c|c|c|c|c|c|c|}
\hline Sign & $\mathrm{SiO}_{2}$ & $\mathrm{MnO}$ & $\mathrm{Al}_{2} \mathrm{O}_{3}$ & $\mathrm{CaO}$ & $\mathrm{MgO}$ & $\mathrm{CaF}_{2}$ & FaF & $\mathrm{TiO}_{2}$ \\
\hline A & - & - & - & - & 一 & 50.0 & 55.0 & - \\
\hline B & 28.5 & - & - & 26.5 & - & 45.0 & - & - \\
\hline C & 8.0 & - & - & 14.0 & - & 37.0 & - & 35.0 \\
\hline E1 & 47.3 & 17.1 & 2.5 & 24.9 & 7.8 & - & - & - \\
\hline $\mathrm{E} 2$ & 40.4 & 14.8 & 2.4 & 24.0 & 9.4 & 99.2 & - & - \\
\hline E3 & 30.7 & 12.1 & 2.3 & 20.4 & 11.0 & 3.6 & - & - \\
\hline
\end{tabular}




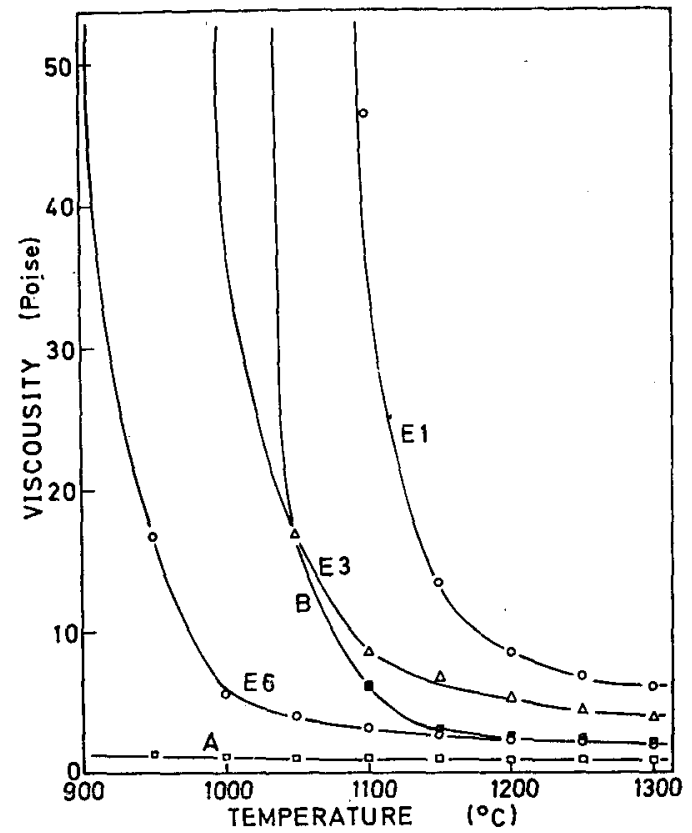

Fig. 2 Relation between temperature and viscosity for each slag.

を入れて，タンマン炉によって加熱し，その冷却途上に 扔ける粘性の変化を内円柱を回転させることによって生 じた回転モーメントを連続的に計測して測定した。なお 粘性は次式によって計算した。

$$
\mu=\frac{M}{4 \pi h}\left(\frac{1}{r_{1}^{2}}-\frac{1}{r_{2}^{2}}\right) \frac{1}{2 \pi h}
$$

$\mu:$ 粘性 (poise $=$ dyne $\left.\cdot \mathrm{sec} \cdot \mathrm{cm}^{-2}\right), M:$ 回転モーメン $卜$ (dyne $\cdot \mathrm{cm}), r_{1}$ : 内円柱の半径 $(\mathrm{cm}), r_{2}$ 外简の半 径 $(\mathrm{cm}), h:$ 円柱の高さ $(\mathrm{cm}), n:$ 回転数 $\left(\mathrm{sec}^{-1}\right)$

温度は $13 \% \mathrm{Pt} / \mathrm{Pt} \quad \mathrm{Rh}$ 熱電対をアルミナ保詖管でつ つみ,アルミナ製接着剂で密閉した後,ルッボの側壁に 埋め込んで測定した．灯内の温度は場所により $40 \sim 50$ ${ }^{\circ} \mathrm{C}$ 程度の差があった，最高加熱温度は，実験装置の都 合上 $1300^{\circ} \mathrm{C}$ までとした。各種フラックスの粘性測定結 果を Fig. 2 亿示す.

粘度は E1，E3，B，E6，Aの順に小さくなってい る.とくにフラックス $\mathrm{A}$ の場合は, $950^{\circ} \mathrm{C}$ 以上のすべて の温度で 1 ポアズ前後の低粘性を示しているが，てのよ うに粘性が低い場合は，実際の溶接の亡きにわずかのす き間からあスラグがあれる可能性がある.しかしなが ら，一般には流出の途中で冷却されて粘性が低くなるの で，粘性が低䢔ぎることはそれほど問題ではなく，スラ グの巻込防止，ガスの脱出などの点からは，かえって都 合がよい。

これに対し，一般鋼用であるスラグ E1 の粘性はもっ
とも高い，しかし，鋳鉄の凝固温度である $1200^{\circ} \mathrm{C}$ 付近 ではまだ 8 ポアズ程度で，常温でのグリセリンの粘性 $\left(20^{\circ} \mathrm{C} \Rightarrow 14\right.$ poise $)$ よりも小さい，そのため，前報での 溶接実験結果でも明らかなように，このスラグ E1 を用 いても溶接は可能である。しかし；このスラグの 1200 ${ }^{\circ} \mathrm{C}$ 以下での粘性は急速に大きくなり， $1100^{\circ} \mathrm{C}$ では数 10 ポアズにあなるので，アークなどが発生して溶接が不安 定になった場合は溶接金属よりあスラグの方がさきに凝 固する可能性もあり，スラグ巻込なぞの溶接欠陌をつく る原团になるとみられる。

$\mathrm{E} 1$ に $\mathrm{CaF}_{2}$ を $9 \%$ 加えた $\mathrm{E} 3$ は， $1100^{\circ} \mathrm{C}$ ですまだ 8 ポアズ程度なので，溶接性は E1 よりあ良好と思われ る、しかし，スラグ内のガスを迅速に浮上させることが できるほどは高温での粘性は低くなく、アークが発生し やすかった.

B 屯 E3 と同様の粘性をもっているが，次節で示すよ うに，電導度はBの方がかなり大きいため，実際の溶接 性については，大きな差があるすのと思われる。

てれに対し， $\mathrm{E} 1$ 亿 $\mathrm{CaF}_{2}$ を23\%加えた $\mathrm{E} 6$ は， $\mathrm{E} 1 や$ E3 よりあ高温での粘性は小さく, 鋳鉄の凝固温度より あ約 $200^{\circ} \mathrm{C}$ 低い $1000^{\circ} \mathrm{C}$ であ 5 ポアズであった。これは 軟䤱の凝固点より約 $200^{\circ} \mathrm{C}$ 低い $1300^{\circ} \mathrm{C}$ での粘性が, 6 柠ズである鋼用フラックス $\mathrm{E} 1$ の特性とよく似てい る。次章の溶接実験でも，とのスラグによりもっと字安 定な溶接がえられたてとから，鋳鉄の溶接には，粘性に ついては E6 程度の值であれば，良好な溶接結果が期待 できるものと考えられる。

なお，フラックスCの粘性は，測定中に回転が不規則 になったりしで测定できなかった．てれは $\mathrm{TiO}_{2}$ の還元 による Ti の析出, および CO ガスの発生などによって 回転に不規則が生じたためと思われる。

\section{2 電気伝導度の测定法およひ結果}

溶础スラグの電導度測定は，精鍊，製鋼な゙゙工業的に む意義をむつため，とれまでにも比較的多く测定されて いる.しかし，その得られた結果は，測定誤差以上の差 が認められ，結論は必ずしあ一致していない。

電気分解吊電気伝導の測定によって, 溶融酸化物の多 〈はイオン電導を示すととがわかっている゙ ${ }^{67) . と れ ら ~}$ のイオン電導体は電流を通じるととによって電気分解を 招てすため, 融液の組成が変化したり, スラグ一電極界 面に分極現象が生じたりして, 正確な電導度を求めるて とはむずかしい。

そこで一般には， $400 \mathrm{~Hz} 20 \mathrm{KHz}$ の交流を通じて測 定を行なうことによって，ての分極による二重層の影響 を小さくしているが，理想的には周波数を無限大まで外 插した場合の電導度が真の值に近いとされている。 
このような，電極界面の分極現象は，周波数に依存する 界面インピーダンスとして表わされるが，てれらはスラ グの発熱現象に重要な役割をむつとされている8 ${ }^{8)}$ 。 また ，てのインピーダンス成分は，ときには直流成分の数倍 の抵抗值を示すこと6あるが, 本エレクトロスラグ溶 接のような，スラグ浴が小さい場合のインピーダンス成 分と直流抵抗成分上の比は，一層大きくなると思われ る.

その他，スラグに通電したときの熱は，スラグの抵抗 熱よりも、スラグが分解して生成したガス層を電流が流 れるととによって生じるあのであるとの説あある97。 の場合はイオン化した $\mathrm{CaF}_{2}$ の蒸気中にアークがとぶて とによって発熱するするすのとされている。

また，本黒鉊ノズル式エレクトロスラグ溶接の場合は スラグー黒鉛電極界面において，C $(\mathrm{g})+\mathrm{O}^{2-}$ (in slag) $=\mathrm{CO}(\mathrm{g})+2 \mathrm{e}$ の反応 $\left.{ }^{9}\right)$ 生じるので, 乙れ化よっても 测定值は異なってくる，以上のほか儿る，電導度汇影響 を与えるいくつかの現象が報告10)されているので，エレ クトロスラグ溶接の発熱現象とそのまま結びつくような 抵抗值を测定するととは非常にむずかしい.

そのため，命回は一般鋼用スラグである E1 の抵抗值 と、試作したスラグの抵抗值とを比較する意味で測定を 行なった.なお、スラグの测定值を真の值に近ずけるた めには，できるだけ高い周波数で測定するのが望ましい が,一般のエレクトロスラグ溶接は，直流または商用周 波数が使われていることから, 測定も $50 \mathrm{~Hz}$ の商用周 波数によって行なった。

Fig. 3 亿電導度測定回路を示す. 溶融したスラグ中に 插入した 2 本の白金電極間に交流電王を加え，徐冷しな がら各温度における端子電圧および電流を記録し, 得ら れた結果を， $\mathrm{KCl}$ 水溶液によって補正して電導度を算出 した.

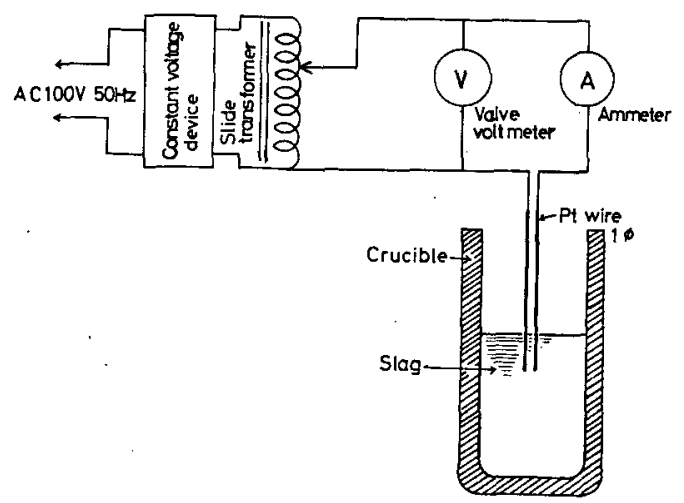

Fig. 3 Measuring method for electric conductivity of molten slag.

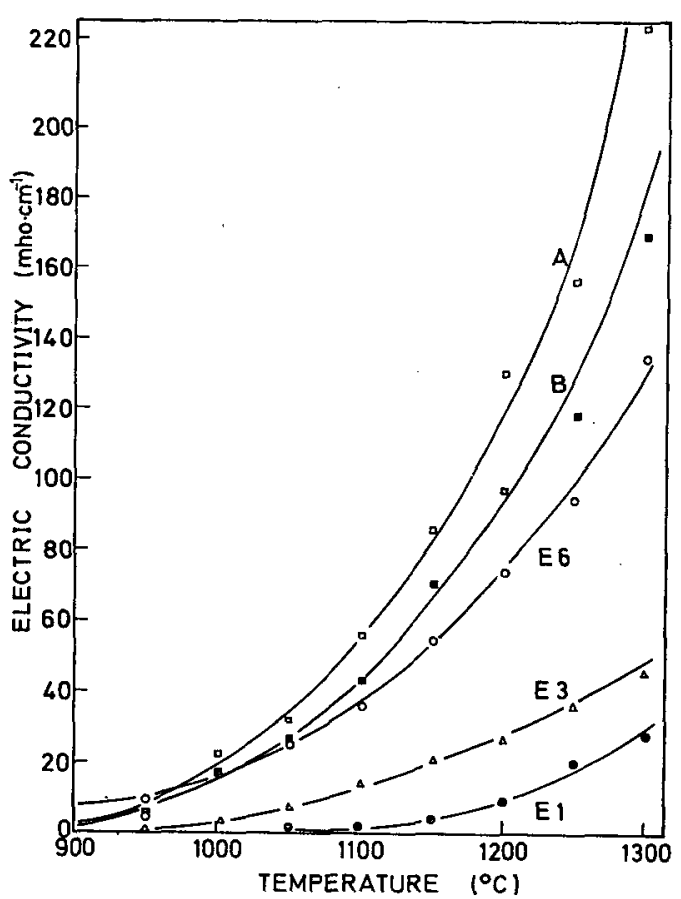

Fig. 4 Relation between temperature and electric conductivity for each slag.

なお，物性定数表などに揭載されている標準水溶液の 抵抗値は，一般に周波数依存性のきわめて少ない白金黒 鍍金白金電極を用いて測定されているが，本測定では平 滑白金電極をそのまま用いている。

測定されたそれぞれの電導度を Fig. 4 亿示す.

前節でもっ之も低粘性を示したスラグAの電導度がも つと屯大きく，次いで $\mathrm{B}, \mathrm{E} 6, \mathrm{E} 3, \mathrm{E} 1$ の順に小さくな っている.

$\mathrm{E} 1$ があっとす小さい電導度をむつが，前報で $\mathrm{E} 1$ を 用いて鋳鉄を溶接したときの溶接制御電代が， $30 \sim 40 \mathrm{~V}$ の間を自由に調整できたことからみて，E1 程度の電導 度があっと屯溶接に適しているのではないかと思われ る.

なお，スラグCの電導度测定は，白金電極の消耗が激 しく，測定できなかった．乙れは回路中に流した電流の ために, 電気分解された Ti が電極に析出して, 白金と 反応したものと思われる。

\section{3 総括}

以上の粘性および電導度の測定結果をまとめると，以 下のようになる。

1）鋳鉄用スラグの粘性は, 軟鋼用スラグである E1 と くらべてかなり低いるのが必要であるが，鋳鉄の融点 が鋼のそれより約 $300^{\circ} \mathrm{C}$ 低いととから，目安としては 鋼用スラグ $\mathrm{E} 1$ の粘性曲線をそのまま約 300 ㄷだけ平 
行移動させたもの上同じような粘性をむつ E6，ない しそれより低い粘性をもつAなどがよいのではない かと思われる。

2）鋳鉄用スラグの電導度がどの程度が適当かは，電気 伝導度を測定しただけでは判断できない。しかし，通 電時のスラグ温度および発熱現象は，軟䤱溶接の場合 も，鋳鉄溶接の場合む，だいたい同じと考えてよい。 したがって，軟鋼用スラグとして適切な電導度をもつ $\mathrm{E} 1$ 亿近い電導度をむつスラグならば，鋳鉄の溶接に も差しつかえない之思われる，すなわち，箸純に考沅 れば E1 程度の電導度があっともよく，以下 E3，E6， B，A の順に電導度が大きくなるほぞ，溶接には不適 当なスラグになるあのと考えられる。

\section{4. 試作フラックスによるエレクトロスラグ 溶接実験}

以上の試作フラックスの物性と，溶接への適用性との 関係を調べるため，てれらのフラックスを用い実際に鋳 鉄にエレクトロスラグ溶接を行なった場合について，以 下にのベる実験を行なった。

\section{1 実験方法}

溶接は前報1で開発した黒鉛ノズル式エレクトロスラ グ溶接法をそのまま用いた。溶接ワイヤも前報1で開発 されたものの一つ（白鋳鉄粉末に Fe-Si を 5 \%梁加し た混合粉末を，軟鋼製チューブの中に范增率として $40 \%$ つめたもの）を用いている，装置およびワイヤ断面形状 を Fig. 5 に示す、試験片は $200 \times 250 \times 40 \mathrm{~mm}$ のミ一八 ナイト鋳鉄を用いた。溶接電流は直流正極性で 500 700 Amp. 溶接電压 $20 \sim 40 \mathrm{~V}$, 溶接速度 $2 \sim 10 \mathrm{~mm} / \mathrm{min}$

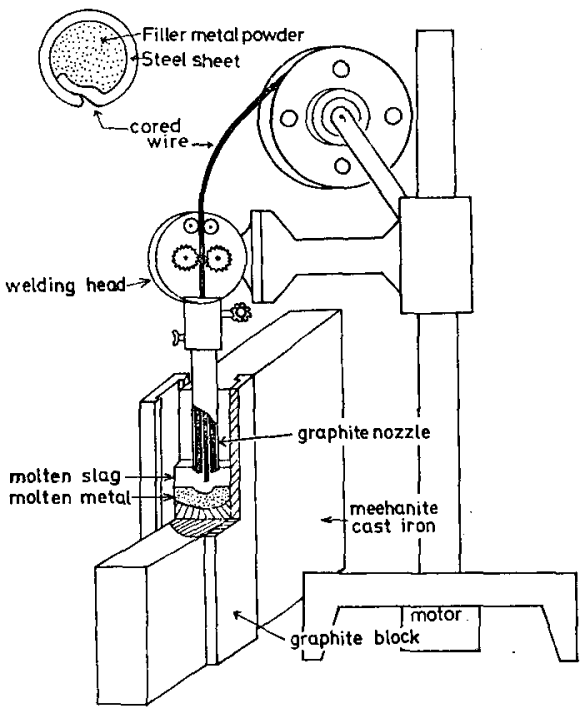

Fig. 5 Schematic view of electroslag welding.
程度である，なお，直流を用いたのは，大容量の交流電 源がなかったためであり他意はない，

この黒鉛ノズル式溶接法が一般のエレクトロスラグ溶 接法とことなる点は，ワイヤの送給を手動（自動制御な し）とし，そのかわりにスラグ溶中にある黒鉊ノズル先 端と，母材との間の電圧を検出することによって黒鉛， ズルの位置を自動制御していることである。このように すると，溶接ワイヤの送給を停止させてあ黒鉊ノズルか ら常に溶接電流が流れるので，入熱をいくらでも大きく するととができる，また，粉末充填率が高く，溶解しに くい充填ワイヤであってむ十分に溶解させることが可能 である.

なお， X線イメージインテンシファイヤによって溶接 中のアーク現象やスラグの挙動などむ同時に観察した。 X線観察のプロックダイヤグラムを Fig. 6 江示す. $280 \mathrm{kV} 3 \mathrm{~mA}$ のX線出力による像をイメージ管を通し てTVカメラによって撮影し，ビデオテープレコーダに 記録した。

\section{2 溶接中の溶融スラグの直接観察}

各種フラックスによる溶接現象を以下にのべる。

フラックスA‥状態図によるとこのスラグの融点は $950^{\circ} \mathrm{C}$ 程度であり，前節の粘性測定でもすつとも低い值 を示している，そのため，溶接時の粘甠む非常に低い之 思われるが，当て板のすき間からスラグが流れ出るよう なととはなかった。

しかし，このスラグは電導度がとくに大きいため，ス ラグ中に電極を哚く浸漬することができなかった，その ためスラグプールをよほど浅ぐしないと，溶接電流のほ とんどがスラグ表首部を通って㑡面の鋳鉄母材に流机て しまい，溶接金属プールの温度が低下した。なお，スラ グプールを浅くした場合は溶接ワイヤが溶融しないうち に金属プール飞突込んでしまったり，黒鉊ノズル先端が スラグ溶から離れて，スラグ表面との間にアーク放電を おとしたりして，安定した溶接ができなかった。

なお，溶接中にフラックスを添加した場合，その直後 はフッソガスと思われる刺激性のガスが多く発生する が，気泡は小さく，その上昇速度は非常に大きい，しか しスラグ温度が低いため母材溶接部の温度を十分に高く することができず，溶融スラグと鉱鉄とのぬれは悪い。

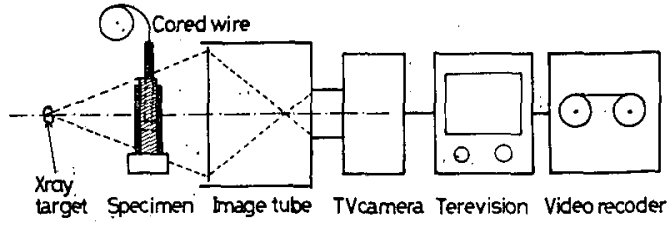

Fig. 6 Outline of direct observation of molten slag during welding by $\mathrm{X}$-ray inspection. 
そのため溶接部はスラグ巻込が多く, 不完全であった.

フラックスス $\mathrm{B} \cdots \mathrm{A}$ 亿つで電導度の大きいスラグであ るが, 溶接電圧は $25 \mathrm{~V}$ 程度に保持することができた。

発生するガスの量はかなり多いが気泡の大きさは小さ く, そのの脱出速度もかなり早い. 気泡の脱出とともに スラグの一部は飛散して鋳鉄壁面に付着するが, 付着し たスラグはスラグプールにもどりにくい.そのためスラ グ量を一定に保つことがむずかしく, 溶接む比較的不安 定であった. なお, このフラックスも鋳鉄母材を十分に 溶融するには熱量が不十分で, スラグと鋳鉄とのぬれは よくない.

フラックスC…とフラックスはソ連で開発され, 一 般にあ使われているあのである. 粘性, 電導度とも測定 できなかったが, $\mathrm{CaF}_{2}$ あ多く入っているので低粘性が 予想された. しかし， X線テレビによる気泡の観察で は, 大きな気泡が発生し, その上昇速度も遅く鋳鉄への ぬれはあまりよくない.なお，乙のスラグは典型的な組 成である $\mathrm{CaF}_{2}, \mathrm{CaO}, \mathrm{SiO}_{2}$ などのほかに, 酸化物の生 成自由エネルギの高い $\mathrm{TiO}_{2}$ が35\%む入っている. その ため, 炭素により還元された多量の Ti によって, 高融 点となったスラグが黒鉊の当て板と溶接部との間に多量 につき, それがスラグ巻込として溶接欠陥をつくった． なお，との付着したスラグは $\mathrm{Ti}$ を $50 \%$ 以上含有し，そ の他はほとんどが $\mathrm{Ca}$ であり $\mathrm{Fe}, \mathrm{Si}, \mathrm{F}$ などは微量で あった。

フラックス $\mathrm{E} 1 \cdots$ の 鋼用スラグは, 粘性が高いた め, ガスの脱出速度は遅く, 気泡も大きい。乙の気泡の 停滞によってスラグ中の通電が防げられるので, その部 分の電流密度が増し, 電極周辺の急激な温度上昇をおこ す.その結果スラグのガス化む一層激しくなって大きな 気泡が生じ，その部分にアークを放電するものと思われ る.アークが発生した場合は溶接は一層不安定になりス ラグ巻込などの久陥が生じやすい，との傾向は, 電流を 增すと一層顕著になる。

フラックス E3，E6‥E3 は E1 よりも溶接安定性が かなりよくなり, $500 \mathrm{Amp}$ 程度ではアークが発生しな い. しかし $700 \mathrm{Amp}$ ではガス量む多くなりアーク放電 する.これに対し，E6 は新しくスラグを投入したとき のみガスを発生するが, その上昇速度は速く, 気泡も小 さい，電流を小さくした場合は，正極側の黒鉛当て板付 近からわずかにガスの発生がみられるだけであるが, 電 流を大きくした場合はスラグ全体に細かい気泡がみられ た.

このガスの固形成分を水冷銅板により採集したとこ ろ, $\mathrm{Ca}, \mathrm{Mn}$ を多く含んでいたが, $\mathrm{Si}$ はほとんぞ検出 できなかった。この他にあ, $\mathrm{CO}, \mathrm{CO}_{2}, \mathrm{~F}_{2}$ ガスなどが

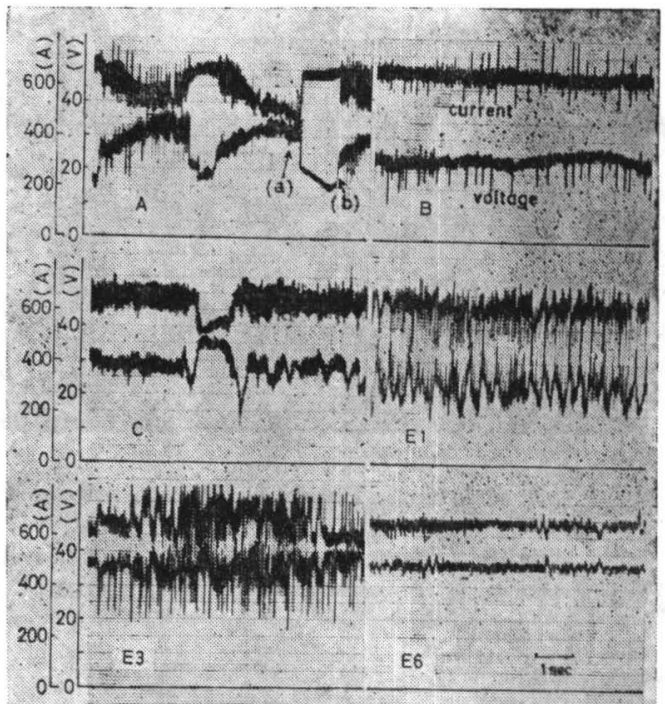

Fig. 7 Oscillograms showing the variation of current (upper) and voltage (lower) during electroslag welding.

含まれていると思われる。なお，E6 の溶接安定性は非 常によい.

Fig. 7 に各種スラグによって溶接した場合の, 電流, 電圧波形を示す.

あっとあ電導度の大きいスラグ $\mathrm{A}$ は, 溶接電圧を $30 \mathrm{~V}$ 程度に低くしてもアーク放電している( $\mathrm{a}$ 点). との放電 は，電極をスラグに接触するまで下げてやると止むが， スラグの電導度があまりにあ大きいため, その瞬間に電 圧は $20 \sim 15 \mathrm{~V}$ 程度にまで急速に降下する, このように 低い電圧でありながらその 1 秒後(b)に再びアーク放電が おこっているのは, 電極の囲りのスラグ温度が高くな り，ガス化しやすくなったためと思われる.

これに対し, スラグ Bは溶接電圧を $20 \mathrm{~V}$ 程度に保持 でき, 電流, 電圧とも安定していた. しかし, 入熱が小 さく，溶接は不良であった。

スラグ $\mathrm{C}$ は, $\mathrm{E} 6, \mathrm{~B}$ に次いで安定な電圧, 電流波形を 示したが， $\mathrm{TiO}_{2}$ の還元によるスラグの巻込など，スラ グの粘性や, 電導度以外の原因によって溶接不良が生じ たようである，

スラグ E1, E3 は, 粘性が高いために停滞したガス部 分にアーク放電をおこし, 溶接不良を生じた。 それに対 し E6 は電圧を $35 \sim 40 \mathrm{~V}$ 程度に設定できる上に電流, 電圧の変動も少なく, 安定した溶接ができた.

Photo. 1 に, 各種フラックスを用いて溶接した溶接部 外観を示す.

E6 は完全な溶接部が得られたが, 他のものにはスラ グの巻込などがあり， Cのようにほとんど溶接されてい ないのもあった。 


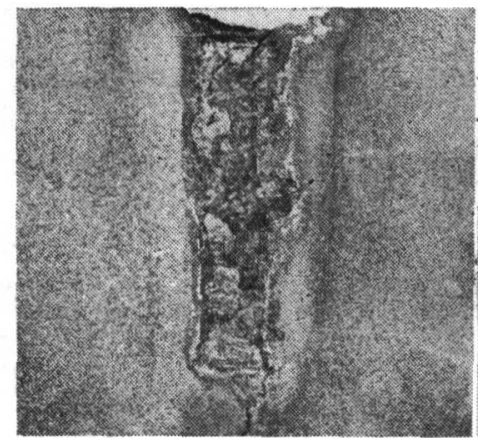

(C)

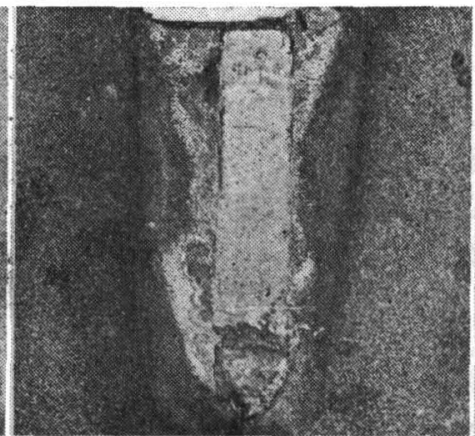

(E1)

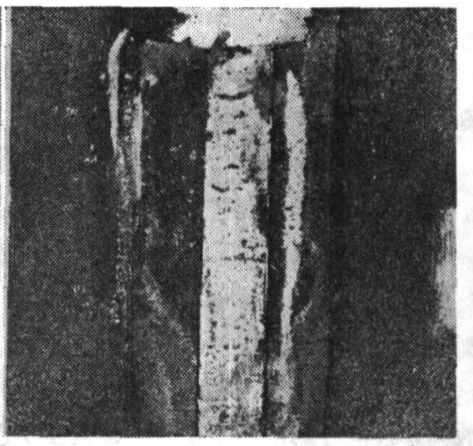

(E6)

Photo 1. Outward appearance of electroslag weld of cast iron.

Table 2 Results of chemical analysis of weld metals in electroslag welding by using of each flux.

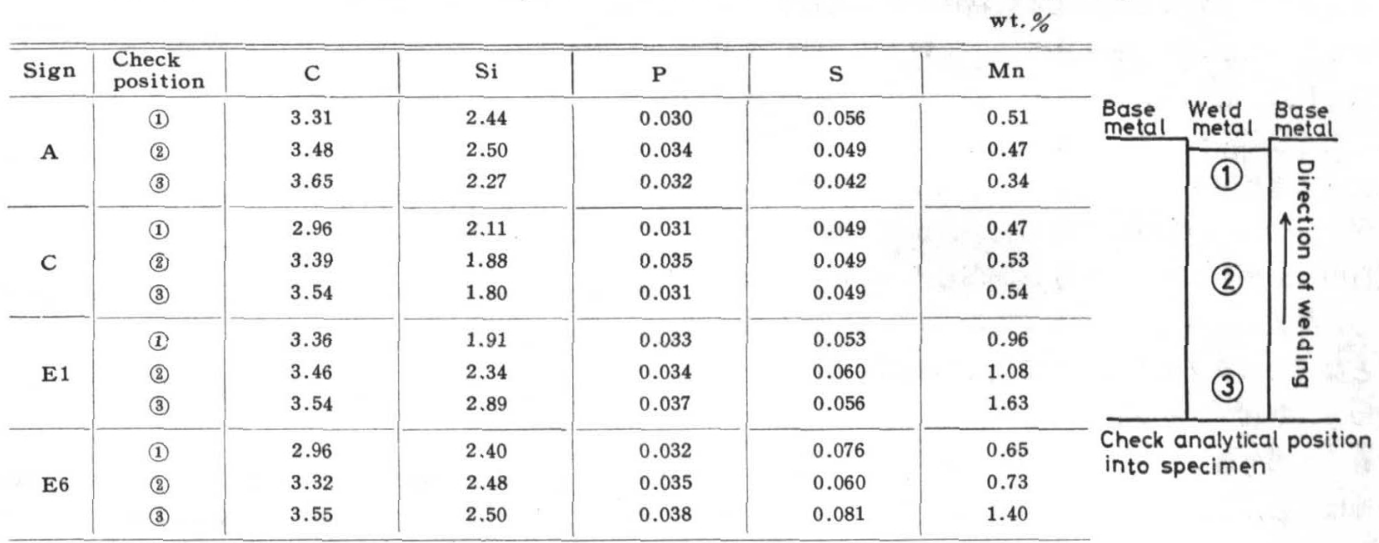

Table 3 Change of chemical composition in welding flux by welding.

\begin{tabular}{|c|c|c|c|c|c|c|c|}
\hline \multicolumn{2}{|c|}{ Sign } & \multirow{2}{*}{$\begin{array}{c}\mathrm{SiO}_{2} \\
25.1 \\
18.1\end{array}$} & \multirow{2}{*}{$\begin{array}{c}\mathrm{MnO} \\
-\end{array}$} & \multirow{2}{*}{$\frac{\mathrm{Al}_{2} \mathrm{O}_{3}}{-}$} & \multirow{2}{*}{$\begin{array}{r}\mathrm{MgO} \\
-\end{array}$} & \multirow{2}{*}{$\begin{array}{c}\text { TCaO } \\
56.9 \\
64.0\end{array}$} & \multirow{2}{*}{$\frac{\mathrm{TiO}_{2}}{-}$} \\
\hline B & $\begin{array}{l}\text { flux } \\
\text { slag }\end{array}$ & & & & & & \\
\hline C & $\begin{array}{l}\text { flux } \\
\text { slag }\end{array}$ & $\begin{array}{l}5.2 \\
7.8\end{array}$ & $\overline{-}$ & 二 & $\overline{-}$ & $\begin{array}{l}42.7 \\
38.9\end{array}$ & $\begin{array}{l}35.7 \\
33.6\end{array}$ \\
\hline E1 & $\begin{array}{l}\text { flux } \\
\text { slag }\end{array}$ & $\begin{array}{l}41.9 \\
44.8\end{array}$ & $\begin{array}{l}16.8 \\
8.71\end{array}$ & $\begin{array}{l}3.3 \\
4.1\end{array}$ & $\begin{array}{l}15.7 \\
18.0\end{array}$ & $\begin{array}{l}14.2 \\
17.1\end{array}$ & - \\
\hline E6 & $\begin{array}{l}\text { flux } \\
\text { slag }\end{array}$ & $\begin{array}{l}30.8 \\
30.9\end{array}$ & $\begin{array}{r}11.5 \\
3.3\end{array}$ & $\begin{array}{l}2.9 \\
3.8\end{array}$ & $\begin{array}{l}10.2 \\
10.8\end{array}$ & $\begin{array}{l}30.1 \\
27.0\end{array}$ & - \\
\hline
\end{tabular}

\section{3 溶接金属およびスラグ組成の溶接による変化}

Table 2 にそれぞれのスラグを用いて溶接した溶接金 属の溶接開始部, 中央部, 終了部の化学組成を示す.

$\mathrm{E} 1, \mathrm{E} 6$ など, $\mathrm{MnO}$ 入りのフラックスを用いたもの は，還元された $\mathrm{Mn}$ が金属に移行し，溶接スタート部で の $\mathrm{Mn}$ 量が増している.

この $\mathrm{MnO}$ は, 酸化物の標準生成自由エネルギが使用 している酸化物の中ではあっとあ高く, 不安定な成分で あるが, 一般の鋼におけるエレクトロスラグ溶接では, それほど金属への移行はみられていない，すなわち，て れらは本黒鉛ノズル式エレクトロスラグ溶接法だけの特 殊な現象であると思われる.黒鉛および使用しているス
ラグ組成酸化物の標準生成自由エネルギと温度との関係 をみると ${ }^{11)}, 2 \mathrm{C}+\mathrm{O}_{2}=2 \mathrm{CO}$ の標準生成自由エネルギは, $400^{\circ} \mathrm{C}$ 以下では最も高い. しかし, それ以上では $\mathrm{Mn}+$ $\mathrm{O}=\mathrm{MnO}$ のそれよりあ低くなり, $\mathrm{MnO}+\mathrm{C}=\mathrm{Mn}+\mathrm{CO}$

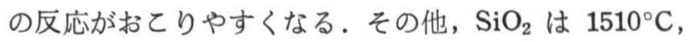
$\mathrm{TiO}_{2}$ は $1620^{\circ} \mathrm{C}, \mathrm{MgO}$ は $1820^{\circ} \mathrm{C} \mathrm{CaO}$ は $2180^{\circ} \mathrm{C}$ 以上 の温度で，Cによって還元されることが可能になる。 本黒鉛ノズル式エレクトロスラグ溶接における溶接中 のスラグ温度は, $1700^{\circ} \mathrm{C}$ 程度なので, $\mathrm{MnO}$ の他に $\mathrm{SiO}_{2}, \mathrm{TiO}_{2}$, などが C によって還元される可能性があ る.

Table 3 に溶接によるスラグ組成の変化を示す. 


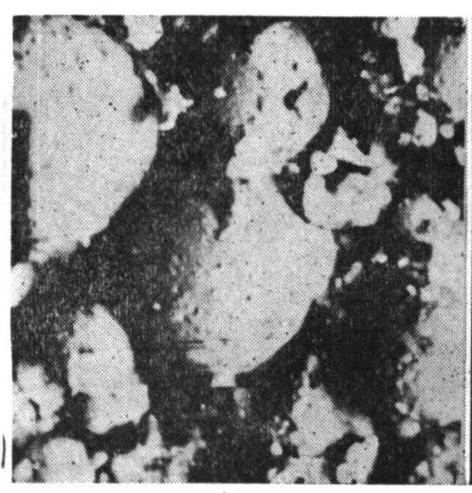

(a)

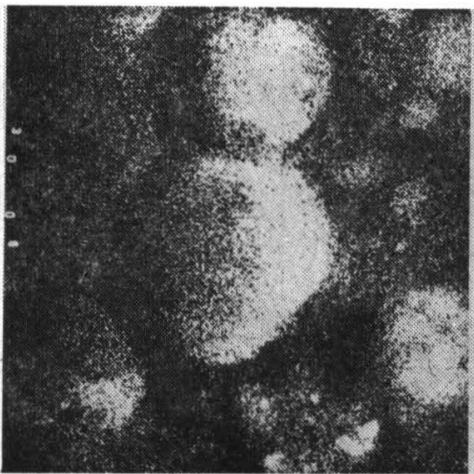

(b)

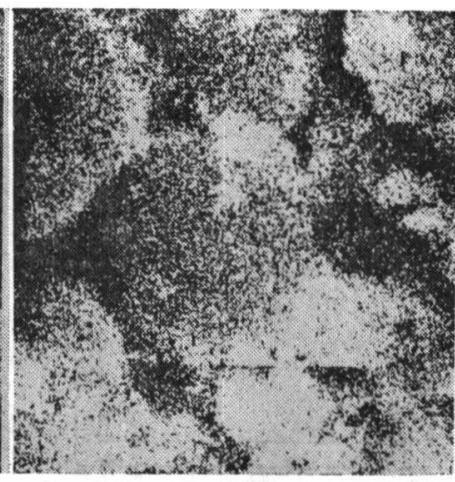

(c)

Photo 2 (a) absorbed electron patern.

(b) Ca X-ray pattern.

(c) Mn X-ray pattern.

$\mathrm{MnO}$ を含むスラグ $\mathrm{E} 1, \mathrm{E} 6$ や $\mathrm{TiO}$ を含むスラグ C などは, それぞれ $\mathrm{MnO}, \mathrm{TiO}_{2}$ が減少している.なお $\mathrm{TCaO}^{*)}$ の増減むみられるが $\mathrm{E} 1$ 以外のむのは $\mathrm{CaO}$ の ほかに $\mathrm{CaF}_{2}$ の減少分も含まれているので, どちらが減 少したのかわからない。

なお, とれらのうち $\mathrm{CaO}, \mathrm{CaF}_{2}$ などは比較的蒸気圧 が高く、また遊離した $\mathrm{Ca}$ は $1480^{\circ} \mathrm{C}$ 付近で気化するの で, 大電流を流したときなど, スラグ温度が異常に高く なった場合は，乙れらの成分の気化などあ考えられる.

Photo 2 は E6 に大電流を流したときに発生したガ スの固形成分を水冷銅板によって採集したあのの X M A 写真であるが $\mathrm{Ca}, \mathrm{Mn}$ などが多く含まれている.

\section{4 総括}

(1) フラックス A, B, は電導度が良すぎるため, 溶接電 圧を $30 \sim 40 \mathrm{~V}$ の適性值に保つととができなかった。と くにフラックス A , 温度上昇によるスラグのガス化に よってアーク放電をおてしやすい，その場合アークの当 っている部分のスラグは高温になり過ぎて，スラグのガ ス化を一層早める一方, アークの当っていない部分の温 度は下り, スラグ巻込などの欠陷をつくった。

(2) フラックスCを用いて溶接した場合は，還元された Ti を多く含む高融点の金属状スラグが溶接部と黒鉛当 て板との間に付着して, スラグ巻込などの欠陥をつくっ た.

(3) フラックス E1, E3 は, 発生したガスがスラグ中よ り浮上しにくいため，アークが発生しやすい，電流を小 さくすればアークの発生を押えるととができるが，入熱 が不足して溶接欠陥がかえって生じやすい. しかし， E6 などは電流を多くした場合でも，アークの発生やス ラグの巻込もなく，良好な溶接ができた.

(4) 鋳鉄は, 強力な還元剂である炭素を多く含有してい
るが、本エレクトロスラグ法は，その上に炭素電極を用 いて溶接を行なうので, $\mathrm{MnO}, \mathrm{TiO}$ など還元されやす い酸化物は,できるだけ含まない方が望ましい.

\section{5．現場における補修溶接への適用}

前章までは, 主に鋳鉄の組立て溶接を対象とした平板 の溶接に関して実験を進め, 当初の目的をほぼ達成する ことができた。

しかし, 現時点における現場においては, 鋳鉄の平板 溶接よりも, 宩埋めなどの補修溶接に対する要求がき わめて強い.

てれまでにあ小型鋳造品に対する小さな欠陥部に対し ては, $\mathrm{Ni}$ 系あるいは共金溶接棒によって補修溶接が行 なわれてきた。しかし，その色調が異なったり，高い予 熱を必要としたり，あるいは溶接割れを防ぐために短い ビードをとび石形に溶接してあとでつないでゆくなど, 過大なコストと労力を必要とし, 大型鋳造品などの大き な欠陥部の補修には適していない。

一方，工作機械や産業機械などは，ますます大型化し ているが，てれらにできた大きな鋳造欠陥部の能率的な 補修ができれば，鋳造コストの低減に大きな役割を果す といわれている.工作機械の場合は, テーブルの摺動面 などに生じた欠陥があっとも大きな障害となるが，乙れ を補修する場合はとくに色調に差がないとと, 収縮割れ が生じないととなどが要求される．色調については共金 金属で溶接すればあまり問題はないが, 補修溶接の場 合，平板溶接之くらべると格段に大きな拘束力を受ける ので, 収縮割れ対策がもっとも重要となる。 このほか, 硬さの差がないことあ重要であるが, 鋳造後には一般に 応力焼鈍が行なわれているので, これによって硬さが低 下できるならば, 溶接直後の硬さが高いととはそれほど 問題ではないと思われる.

以下に現場において行なったテーブルの補修溶接の結 


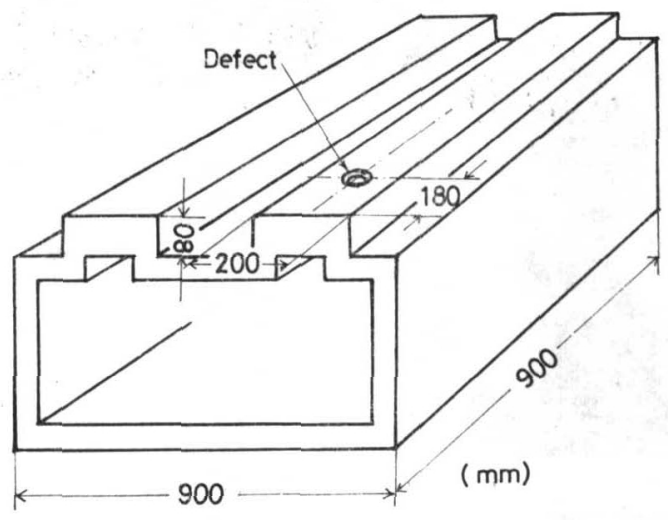

Fig. 8 Schematic view of small-size machine tool table used in repair welding.

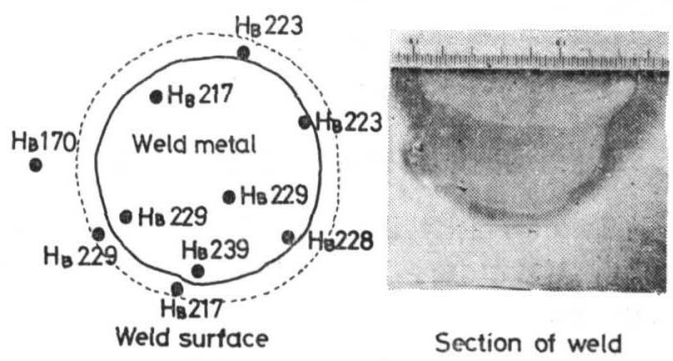

Fig. 9 Hardness measurement and macro-structure in repair weld of smallsize machine tool table.

果を示す. 溶接材料は, 4 章に記した平板溶接のものと 同じあのを用いた.フラックスは E6 を用い，予熱はま ったく行なっていない.

\section{1 小型テープルの補修実験}

Fig. 8 に示すような小型テーブルの一部に, $50 \mathrm{~mm} \phi$ $\times 40 \mathrm{~mm}$ の孔をあけ, ての部分を溶接した. スタート は, まず黒鉛ノズル電極からアーク放電させてれの底部 を溶解し, 金属プールが形成されてからフラックスを投 入して充填ワイヤを送給した.

溶接後の表面硬さおよび溶接部断面形状を Fig. 9 に 示す. 熱影響部を含むブリネル硬さは HB170 229（ピ ッカース換算 $205 \sim 258 \mathrm{Hr}$ ）の範囲であり，溶接のまま でも母材と大きな差はなかった. なお, 表面のきさげ仕 上げをしたとてろ，母材部よりあかえって容易であり， 切削性むよいことがわかった. 溶接スタート部の近くに は, 数力所のスラグ巻込およびブローホールなどがみら れるが, これらはスタート時のワイヤ送給時期をさらに 遅らせることによって防ぐことができるあのと思われ る.なお，乙の場合は熱収樎割れはおこしていない. Fig. 10 に, 深さ方向の硬さ分布を示す. 溶接スタート 部付近の硬さは高いが, 表面から 10 20 mm 以内の硬

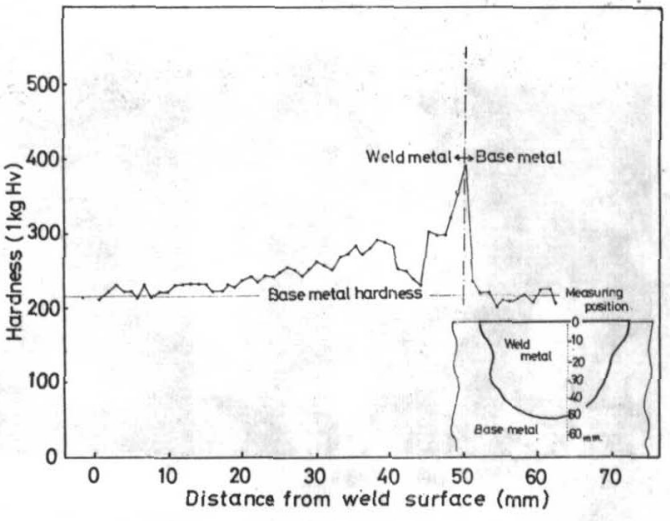

Fig. 10 Hardness distribution in repair weld.

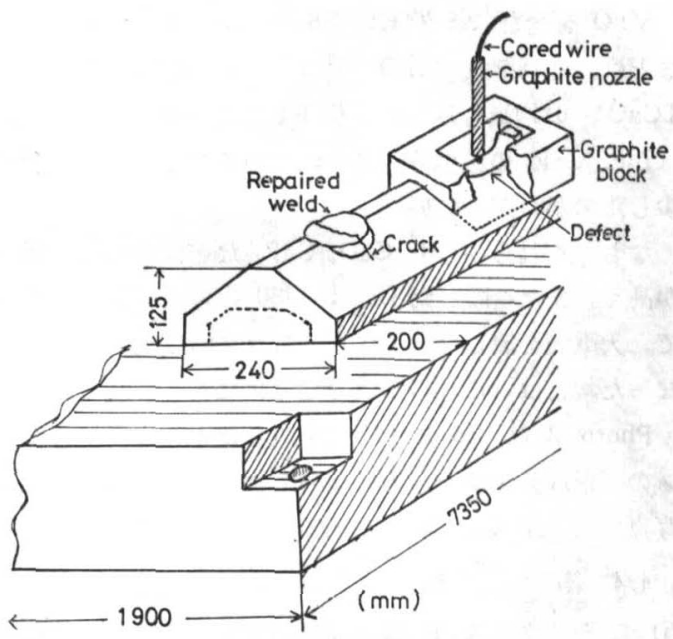

Fig. 11 Schematic view of large-size machine tool table used in repair welding.

さは低く,このままであ摺動面として使えるのではない かと考えられる。

\section{2 大型テーブルの補修実験}

以上のように予備実験では硬さが低く, 収縮割れもお こらない溶接ができたので, 次に実際の大型テーブルの 補修溶接を行なった. テーブルの形状と欠陥部の位置を Fig. 11 に示す. 欠陥部の周囲を図に示したように黒鉛 ブロックで囲み，その中で溶接を行なった．欠陥部の大 きさは，小さなむので $70 \mathrm{~mm} \times 100 \mathrm{~mm}$ ，大きなもので $120 \mathrm{~mm} \sim 150 \mathrm{~mm}$ ああったので, 黒鉛電極を 2 本用い, 補修む, 一つの欠宿部を 2 回に分けて溶接をおこなっ た、 4 力所溶接したが, そのすべてが $200^{\circ} \mathrm{C}$ 前後に冷却 したときに, 図に示すような位置に収縮割れをおこし た、これらの原因としては, 予備実験とくらべて欠陥部 が大きかったことや，欠陷部形状が異ることによる収縮 応力分布の相異などが考えられる. 試料全体を $200^{\circ} \mathrm{C} \sim$ 
$300^{\circ} \mathrm{C}$ に予熱すれば，収縮割れを防ぐことも可能である が，溶接金属に延性があれ估，当然その必要はない，延 性のある鋳鉄としては溶接部を球状黒鉛化することがま ず考えられるが，溶接部を延性鋳鉄にすることは非常に むずかしい。

なお， $\mathrm{MnO}$ を含む $\mathrm{E} 1 ， \mathrm{E} 3 ， \mathrm{E} 6$ などのフラックスを 用いて溶接した場合は，還元された Mnによって溶接金 属が硬くなるとともに，延性む多少低下する．そこでフ ラックス $\mathrm{E} 6$ から $\mathrm{MnO}$ を除いたフラックスをつくって 溶接を行なった，ガスの発生は E6 よりもさらに少なく なり，溶接作業性あ一層良好であった．とのほかにあ鋳 鉄の超塑性現象を利用して収縮割れを防ぐことも考えて いるが，これらについては次報で改めてのべる.

\section{6. 結}

論

以上, 錈鉄溶接用フラックスの開発の過程と, それを 現場での補修溶接に適用した実験の結果をとりまとめる 亡次の結論が得られる。

1) 試作した数種のフラックスについて，スラグの粘性 測定およびそれを用いて溶接現象の直接観察をおてな った結果，スラグの粘性は鉱鉄の凝固温度よりす約 $200^{\circ} \mathrm{C}$ 低い $1000^{\circ} \mathrm{C}$ でもまだ低粘性であるすのが好結 果が得られた。

2）低粘性のスラグは此較的高電導になりやすいが，ス ラグ溶接ではスラグプールが小さいのでとくに低電導 のあのが必要である.E6 程度の電導度でも溶接電圧 の制御は容易であるが，乙れよりもいく分小さい方が 望ましい。

3）本エレクトロスラグ溶接は黒鉊ノズル電極を使う関 係上， $\mathrm{MnO}, \mathrm{TiO}_{2}$ などが比較的還元されやすい，分 析結果によると，とくに $\mathrm{MnO}$ が還元され，E1，E3， $\mathrm{E} 6$ など $\mathrm{MnO}$ が配合されているフラックスは $\mathrm{Mn}$ が 溶接金属中に還元されて溶接部を硬くした。しかし， $\mathrm{E} 6$ から $\mathrm{MnO}$ を除いたフラックスをい用いてを溶接 作業性はほとんど変化はなく，良好な溶接ができた。

4）以上のスラグの粘性, 電気伝導度の測定, 溶接現象 の直接観察を抗てなった結果，てれらと溶接結果の間 の関連性を明らかにすることができた，その結果，鋳
鉄のエレクトロスラグ溶接にはフラックス E6 ないし E6 から $\mathrm{MnO}$ を除いたフラックス $\left(\mathrm{SiO}_{2} 28 \%, \mathrm{Al}_{2} \mathrm{O}\right.$ $\left.5 \%, \mathrm{CaO} 25 \%, \mathrm{MgO} 12 \%, \mathrm{CaF}_{2} 30 \%\right)$ を用いて 溶接した場合が, 電流, 電圧の変動がもっと屯少な く，溶接部外観もよく，溶接欠陷む生じなかった。

5）現場における小型欠陷部の補修溶接では，おおむね 満足できる結果が得られた．しかし大型欠陷部を補修 した場合は熱収縮割れが発生した.大型鋳物の欠陥部 を予熱なしで補修する場合は収縮応力がとく強く働 くので，乙れからは，延性のある溶接金属が得られる ワイヤを開発する必要がある。

本実験を行なうにあたり，鋳鉄材料については東芝機 械 $\mathrm{K} \mathrm{K}$ 取締役兼プラスチック機械事業部長佐藤薰氏，ま た溶接材料の試作については日鉄溶接工業 K K 研究部熊 谷良平主任研究員ならびに，中村成宏氏に，X線観祭に ついては船舶技術研究所神尾昭主任研究員，粘性測定に ついては金属材料技術研究所中川竜一部長ならびに郡司 好喜窒長からそれぞれご援助をお受けした。関係者各位 に厚くお礼申上げる次第です。

\section{文献}

1）石井, 田村, 加藤他：鉄鉄のエレクトロスラグ溶接（第一報）溶接 学会就 Vol. 139 (1970) No. 3 p. 79

2）水野，松村他：エレクトロスラグ溶接について，溶接咍金研究委具 会, 第43回資料，1971年 2 月

3) Ernest, M. Leven; Phase Diagrams for Ceramists. Copyright 1964 The American Ceramic Society.

4) B.E. Paton; Electroslag Welding. Reinhold Pub Corp 1962

5）森一美他：溶接スラグの奄海性について，溶接溶㳯部会，第 3 回シ ソポジウム賀料

6) A.E. Martin, G. Derage; The Electrical Conductivity of Molten Blast-furnace Slags.

Traus. AIME 154 (1943) 105

7) J.A. Kitchener, A.E. Davies; Electric Transport in Liquid Silicates.

Trans Faraday Sos. 48 (1952) 536 $\sim 548$

8）後藤：固体白金と溶嘱酸化物との界面インビーダンス 鉄と鋼 59 (1973) No. 1

9) A, Mitcnell; Proc. 2nd 1nt. Symp. on ESR Tech. Part 1

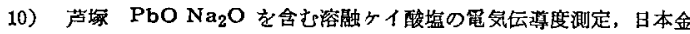
虽学会誌, Vol. 33 (1969) No. 4 p. 498 503

11）新版 金属便㹂，丸善 P. 241 